\title{
The Alleviation Of Allocation Funding And Rural Poverty In Indonesia
}

\author{
Ambya, Nairobi, Muhammad Rizqiandri \\ Faculty of Economics and Business, University of Lampung, \\ J1. Prof. Sumantri Brojonegoro No. 1, Bandar Lampung 35145, Indonesia
}

Corresponding author: aambya.mahmud@gmail.com

\begin{abstract}
Indonesian authority put the fiscal decentralization as one of the policies established to delegate the authority of the central authority to each region to explore sources of income, to benefit the merit in receiving allocations from the higher level of authority, and to organize routine and investment spending. Poverty alleviation is an important agenda for a country to realize the welfare of its people so that poverty alleviation becomes an abroad and massive issue in implementing Sustainable Development Goals (SDGs). This study aims to see how big the influence of fiscal decentralization is, in terms of authority spending, in the form the allocation funding consisting of the General Allocation Funding (DAU), the Special Allocation Funding (DAK) and the Village Funding (DD) on the Poverty Rate in 34 provinces in Indonesia. This paper used a dynamic panel data analysis through the approach Generalized Method of Moment (GMM). The results of this study concluded that the DAU, DAK, and Village Funding variables becoming significantly influencing the rural poverty reduction in Indonesia.
\end{abstract}

Keywords: General Allocation Funding (DAU), Special Allocation Funding (DAK), Village Funding (DD), Poverty.

\section{INTRODUCTION}

The purpose of economic development is to improve the welfare of the community and create an equitable distribution of income (Todaro \& Smith, 2016). The success of the authority in achieving development goals can be assessed from changes in poverty levels. The concept of decentralization contains three main missions, namely creating efficiency and effectiveness in the organization of the regional asset, improving the quality of public services and community welfare, empowering and creating a space for people to participate (participate) in the development process (Barzelay, 1991). So anstudy analytical of poverty which is a reflection of people's welfare in the era of decentralization is important to do. 
Based on the issuance of Law Number 22 of 1999 concerning Regional Authority and Law Number 25 of 1999, Indonesia has established the era of regional autonomy and fiscal decentralization which was marked by concerning Financial Balance between Central and Regional Authority. In this era, the local authority had their own mandate and initiative to organize the regions and the authority to organize their finances to support the performance of regional autonomy. Following the trend of fiscal decentralization policy became a challenge as well as an opportunity for the local authority to organize their asset more effectively and efficiently.

Decentralization is a public policy in order to fulfill public goods more efficiently at the local authority level (Tiebout, 1956). Meanwhile, according to Musgrave (1958) explained that the main role of authority in the economy is as a function of distribution, stabilization, and allocation. The role of authority in maximizing social welfare through the provision of public goods (allocation) must be assigned to lower levels of authority following the principle of subsidiarity also referred to as efficiency criteria which state that goods and services must be provided to the lowest level of authority.

William and Vyasulu (Arini, 2008) suggested that decentralization is expected to be able to reduce poverty if it is directed towards changing political structures and improving governance or changing attitudes between the authority towards the poor. Although the funding allocation annually increases, if not followed by commitment from the authority in its organization, the effort to reduce poverty becomes difficult to achieve maximum results. The performance of fiscal decentralization in Indonesia will produce the expected results if each local authority can implement it in accordance with established regulations. Meeting the basic needs of the community in order to reduce poverty is a significant impact of decentralization policies (Risalam, 2013).

If fiscal decentralization prioritizes public spending, then decentralization will have a direct impact on GRDP, which reflects the economic growth of a region. Infrastructure and social sector spending by regional authority spurs economic growth more than central authority policies. Regions have advantages in making expenditure funding so that they are more efficient by satisfying the needs of the community because they are more aware of the condition of their own regions (Vasquez, 2001).

Based on the importance of fiscal decentralization while on the other hand public welfare tends not to improving significantly, it is necessary to further research how the influence of fiscal decentralization on poverty levels in Indonesia.

\section{LITERATURE REVIEW}


Fiscal Decentralization; there are three variations of fiscal decentralization in a connection to the degree of independence of regional decision making. First, decentralization means the relinquishment of responsibilities within the central authority environment to vertical agencies in the region or to regional authority. Second, the delegation deals with an agency, that is, the region acts as an authority representative to carry out certain functions on behalf of the authority. Third, devolution relates to a situation that is not only performance but also the authority to decide what needs to be done (Bird, 1998).

How far decentralization can be clearly assessed, it depends on whether someone observes it from the top down (bottom down) or (bottom up bottom up). The fiscal decentralization approach from the bottom up generally emphasizes political values, for example improving governance in relation to the willingness to accept suggestions and local political participation and allocation efficiency in terms of improving welfare (Oates, 1972).

Oates (1972) has formulated his idea in a theorem of The Decentralization Theorem. The underlying point is that if there is no cost advantage (scale of results) associated with centralized conditions, then a decentralized pattern of public goods that illustrates the different tastes among regions that will increase welfare compared to the results obtained from decentralization which illustrate a uniform level of output for all regions.

In general, decentralization policies are divided into 3 types (Litvack, 1998): (1) Political decentralization, namely the delegation of greater authority to the regions regarding various aspects of decision making, including setting standards and various regulations. (2) Administrative decentralization, namely the delegation of authority, responsibilities and asset between various levels of authority. (3) Fiscal decentralization, namely the granting of authority to the regions to explore sources of income, the right to receive allocations from a higher levels of authority, and to determine routine expenditure and investment. These three types of decentralization are related to one another and are prerequisites for achieving the goal of implementing decentralization, namely to realize the welfare of the people.

Fiscal decentralization is one of the mechanisms for allocation funding from the State Funding in relation to state financial policies, namely to create sustainable (fiscal sustainability) and provide stimulus for community economic activities (Rahayu, 2014). By then, it is expected that fiscal decentralization will create equal distribution of financial capabilities between regions commensurate with the magnitude of the authority of authority affairs delegated to the autonomous regions.

\section{The Relationship of Fiscal Decentralization with Poverty Rate}


The results of the research of Oates (1993), Martinez and McNab (2001) state that fiscal decentralization can encourage economic efficiency and will dynamically encourage economic growth in a region. They argued that spending on infrastructure and the social sector would be effective in driving the economic growth of a region, because the regions knew the characteristics of their respective regions. So according to this view local authority are believed to be able to allocate funding to the economic sector more efficiently than the central authority does. However, this will not happen if fiscal decentralization does not work effectively (Martinez and McNab, 2001). Furthermore, economic growth and poverty have a very strong correlation, because in the early stages of the development process the poverty level tends to increase and as it approaches the final stage of development the number of poor people gradually decreases (Tambunan, 2011).

The concept of decentralization contains three main missions, namely creating efficiency and effectiveness in the organization of regional asset, improving the quality of public services and community welfare, and empowering and creating a space for people to participate (participate) in the development process (Barzelay, 1991). Arguments in favor of decentralization, among others, were raised by Tiebout (1956), Oates (1972), Musgrave (1958) and as quoted by Litvack et al (1998) who said that the most efficient public services should be carried out by regions that have the most geographical control minimum because the local authority is fully aware of the needs of the community, the decision of the local authority is very responsive to the needs of the community, thus encouraging local authority to make efficiency in the use of funding from the community, competition between regions in providing services to their communities will encourage local authority to increase their innovation. This is the reason why this fiscal decentralization node is at the level of authority that is closest to society geographically. The geographical closeness provides great potential for the region to improve the welfare of its people.

According to Bird and Vaillancourt (1998), the reason that decentralization can help solve national economic problems starts from the basic principle that local authority can provide public services to their people at a lower or more efficient cost compared to the central authority, because local authority know better the needs of their people as well as how to meet these needs in the most efficient manner and the regional authority is closer to its people, so that it will react more quickly when those needs arise, and in the end the community will feel satisfied with the services of the local authority. With the performance of fiscal decentralization the possibility of local authority to accelerate the resolution of the problem of poverty is even bigger.

According to Zulyanto (2010) states that in fiscal decentralization the amount of funding allocations in the regions can have a positive relationship to improving 
people's welfare. Fiscal decentralization can encourage per capita income in the regions so that it can reduce the poor population and conversely low per capita income will increase the number of poor people.

Poverty reduction strategies can be done through income allocations (cash allocations) and growth strategies that favor the poor (pro-poor growth) (De Janvry and Sadoulet, 2010). But what needs to be considered is the decentralization (fiscal) policy which is not automatically pro-growth, pro-poor and pro-jobs need infrastructure support for accessibility and connectivity (Paddu, 2010). This means that there are several conditions for making fiscal decentralization an effect on poverty alleviation in regions that must be met by local authority. Minimum allocation of large amounts of allocation funding is directed to create community empowerment programs or directed to investment in the sectors pro-job and propoor.

Likewise, Sidik (2002) stated that the success of decentralization will depend on the design, performance process, political support both at the level of decision making at each level of authority, as well as the community as a whole, the readiness of authority administration, institutional development and human asset, coordination mechanisms to improve the performance of the bureaucratic apparatus, changes in the value system and bureaucratic behavior in meeting the wishes of the community, especially in public sector services.

In preparing funding allocations, the authority must not get out of the funding objectives. Based on trilogy Musgraves on the purpose of funding allocation, among others are the function of allocation, distribution and stabilization. The allocation function relates to the stock of social goods and the overall process of utilizing asset for the production of private goods, social goods, and combinations of selected social goods. The distribution function is related to the equality of welfare and income distribution in society. While the stabilization function is aimed at stabilizing or maintaining low levels of unemployment, prices or inflation rates, and targeted economic growth.

\section{METHODS}

The type of data used in this study is secondary data. Secondary data used in this study is a combination of time series data and cross section data or what we call pool panel data. Time series data is the period 2015 - 2018 and cross section data is data in 34 provinces in Indonesia. The data collected is in the form of Poverty Level data as the dependent variable and General Allocation Funding (DAU), Special Allocation Funding (DAK), and Village Funding as Source of data derived from the publication of the official website of the Central Statistics Agency (BPS), the Ministry RI's 
finance, and other sources in the form of books, journals, and articles. The data used are DAU, DAK, Village Funding data and Poverty Rate data for 2015 - 2018 in 34 provinces in Indonesia.

The analytical method used in this research is quantitative analysis. The quantitative analysis used in analyzing fiscal decentralization variables on poverty levels in Indonesia is the dynamic panel method. Data processing in this study was carried out using analysis tools in the form of computer software program Eviews 9 with the dynamic panel method (dynamic panel data) through the approach Generalized Method of Moments (GMM).

The following equation is a research model in analyzing variables that affect poverty levels in 34 provinces in Indonesia based on the research model of Caporale et al. (2009):

$\mathrm{TK}_{i t}=\beta 1 \mathrm{TK}_{\mathrm{it}-1}+\beta_{2} \mathrm{DAU}_{\mathrm{it}}+\beta_{3} \mathrm{DAK} \mathrm{K}_{\mathrm{it}}+\beta$ BDAK $(-1)_{\mathrm{it}}+\beta 5 \mathrm{DD}_{\mathrm{it}}+$ either

According to Nachrowi (2006), to make the value of the variables to be analyzed to be balanced while showing the coefficient of slope on the results of the regression output which is the level of change in the dependent variable (percent) if there is a change in the independent variable (percent), then the model will be transformed into log-natural form so that the model becomes:

\section{$\ln \mathrm{TK}_{i t}=\beta 1 \ln \mathrm{TK}_{\mathrm{it}}-1+\beta_{2} \ln \mathrm{DAU} \mathrm{U}_{\mathrm{it}}+\beta 3 \ln \mathrm{DAK} \mathrm{Kit}+\beta 4 \ln \mathrm{DAK}(-1)$ it $+\beta 5 \ln \mathrm{DD}_{\mathrm{it}}$} $+e$ it

Where:

TKit $=$ Poverty Rate in Indonesia for 2015-2018

TKit-1 = Poverty Rate in year t-1 in Indonesia

$\beta=$ Regression coefficients

DAUit $=$ General Allocation Funding

DAK(-1)it $=$ Special Allocation Funding previous year

DAKit $=$ Special allocation Funding

DDit $=$ Funding Village

eit $=$ Standard error

\section{RESULTS}


GMM Specification Test estimated through the approach Generalized Method of Moment (GMM) in this study uses dynamic panel data. This test is carried out on data that will be used to analyze the effect of fiscal decentralization on poverty levels. To find the best model, it must meet several criteria, namely consistent estimators, valid tools, and unbiased predictors (Firdaus, 2011). The consistency of the estimator is shown by the Arellano-Bond (AB) estimation results.

Based on Table 1, the AB estimation results are shown by the statistical value of $m_{1}$ $(-2.671792)$ which is significant at 5\% significance level and the value statistics of 2 (NA or Not Available) which is not significant at the $1 \%, 5 \%$ or $10 \%$. The insignificant statistical value of $m_{2}$ indicates the lack of a second order serial correlation in the residuals from the different specifications, so the estimator can be said to be consistent.

Table 1. Serial Correlation of Arellano-Bond

\begin{tabular}{lcc}
\hline Test Order & m-Statistic & Prob. \\
\hline$A R(1)$ & $-2,671792$ & 0,0075 \\
$A R(2)$ & NA & NA \\
\hline
\end{tabular}

Source: Results of Data Processing with Eviews 9

Furthermore, the validity of the tool can be carried out using the civic test. The tool validity test is used to see the possibility of bias in the estimation parameters due to incorrect use of tool variables in the equation. To test the validity of tool variables, this study uses the Sargan Specification Test as suggested by (Arellano and Bond, 1991), with a null hypothesis that is found to conditions of moment have valid in the model. The following table shows the results of the validity test on the tool variables used in the analysis:

Table 2. Test Validity of Tool

\begin{tabular}{lr}
\hline \multicolumn{1}{c}{ Methods } & Prob (J-statistic) \\
\hline Hiptesis null $\left(\mathrm{H}_{0}\right):$ Condition of Moment Valid & \\
Sargan Spesification Test & 0,104841 \\
\hline
\end{tabular}

Source: Results of Data Processing with Eviews 9

Based on the results of the tool validity test using the Sargan Specification Test shows the probability value ( $\mathrm{J}$-statistic) above $5 \%$, ie $0.104841>0.05$ then $\mathrm{H} 0$ is accepted. This means that the finding of condition of moment in the tool variable used (the tool used is valid). While the properties are not biased(Unbiased)on the probe can be seen from the results of the estimated coefficient values which are 
among the pooled least square (PLS) and fixed effects (FE). In Table 3., the coefficient values from the estimated results lag Ln Tk. Poverty using GMM is 0.299148 which is greater than the value of the coefficient lag Ln Tk. Poverty on FE (0.249338) and smaller than the coefficient value lag Ln Tk. Poverty in PLS (0.993080). So it can be said that the estimator is unbiased.

Table 3. Results of Estimated Parameters and Allocations to the Poverty Level Indonesian

\begin{tabular}{lccc}
\hline \multicolumn{1}{c}{ Parameter } & Koefisien & Std. Error & Prob. \\
\hline FD-GMM & & & \\
\hline Ln Tk. Kemiskinan (-1) & 0,299148 & 0,103162 & 0,0051 \\
\hline Ln DAU & 0,581076 & 0,167773 & 0,0010 \\
\hline Ln DAK & $-0,130237$ & 0,051451 & 0,0139 \\
\hline Ln DAK (-1) & $-0,057227$ & 0,011032 & 0,0000 \\
\hline Ln Dana Desa & -0.103851 & 0,025024 & 0,0001 \\
\hline Pooled Least Square & & & \\
\hline Ln Tk. Kemiskinan (-1) & 0,993080 & 0,008587 & 0,0000 \\
\hline Fixed Effect & & & \\
\hline Ln Tk. Kemiskinan (-1) & 0,249338 & 0,115004 & 0,0339 \\
\hline
\end{tabular}

Source: Data Processing with Eviews 9

While the properties are not biased (Unbiased) on the probe can be seen from the results of the estimated coefficient values which are among the pooled least square (PLS) and fixed effects (FE). In Table 3., the coefficient values from the estimated results lag Ln Tk. Poverty using GMM is 0.299148 which is greater than thief value the coefficient lag Ln Tk. Poverty on FE (0.249338) and smaller than the coefficient value lag Ln Tk. Poverty in PLS (0.993080). So it can be said that the estimator is unbiased.

Hypothesis testing was carried out in this study through the approach Generalized Method of Moment (GMM). The hypothesis test decision is partially based on the probability value obtained from the results of data processing. The probability value is if the significance level $<5 \%$ then $H_{0}$ is rejected while $H_{a}$ is accepted then if the significance level of $>5 \%$ then $H_{0}$ while $H_{a}$ rejected.

Table 4. Estimated Results of Generalized Method of Moment (GMM)

\begin{tabular}{lcrr}
\hline \multicolumn{1}{c}{ Variabel } & \multicolumn{1}{c}{ Koefisien } & t-statistic & \multicolumn{1}{c}{ prob. } \\
\hline LN_TK_KEMISKINAN(-1) & 0,299148 & 2,899783 & 0,0051 \\
\hline LN_DAU & 0,581076 & 3,463467 & 0,0010 \\
\hline
\end{tabular}




\begin{tabular}{llll}
\hline LN_DAK & $-0,130237$ & $-2,531299$ & 0,0139 \\
\hline LN_DAK(-1) & $-0,057227$ & $-5,187186$ & 0,0000 \\
\hline LN_DANA_DESA & $-0,103851$ & $-4,149993$ & 0,0001 \\
\hline
\end{tabular}

Source: Results of Data Processing with Eviews 9

\section{Reporting Research Results}

\section{Variable General Allocation Funding (DAU) to Poverty Level}

Test results Generalized Method of Moment, General Allocation Funding variable (DAU) ) the current period (t) obtained a coefficient value of 0.581076 , has a $t-$ statistic of 2.899783 with a significance of 0.0051 . Significance value is greater than 0.05 indicated that the General Allocation Funding (DAU) of the current period ( $t$ ) has a positive and significant effect on the current Poverty Rate (t), so the first hypothesis is accepted.

The phenomenon found in this study indicates that increasing DAU each year tends to increase poverty in Indonesia. The results are contrary to the expectations of this authority there is a possibility that the increase in DAU is more used to pay salaries of local authority officials who do not have a direct impact on poverty reduction. Increasing the income of the regional authority apparatus is not followed by an increase in the quality of public services provided to the community.

This is supported by the research of Heru Syah P. (2017) who said that the utilization of DAU is not used effectively to reduce poverty, but rather is used more for regional authority expenditure, such as regional apparatus salaries. Increasing the income of the regional authority apparatus is not followed by an increase in the quality of public services provided to the community. This phenomenon also made it possible that the influence of DAU on poverty levels is not immediately felt in the same year, it could be in the next year or the next 2 years.

\section{Variable Special Allocation Funding (DAK) of the current period (t) and the Special Allocation Funding (DAK) of the previous period (t-1) to the current period of Poverty Rate $(t)$.}

Based on the results of the analysis regression using the Generalized Method of Moment (GMM) approach for the current Special Allocation Funding (DAK) variable and the Special Allocation Funding (DAK) variable in the previous period (t1) shows that every $1 \%$ increase in the Special Allocation Funding (DAK) will reduce the current Poverty Rate (t) by $0.130237 \%$ and $0.057227 \%$, so that the second hypothesis is accepted. The findings of the analysis show that the research hypothesis 
which suggests that there is a negative and significant relationship between the funding allocations of the Special Allocation Funding (DAK) to the level of poverty in Indonesia is proven.

Based on the details of its use, DAK Physical and Non-Physical has more direct impact on the community than DAU. The provision of public facilities and infrastructure as well as operational support in the administration of public services has an important contribution in alleviating poverty in Indonesia. Therefore, an increase in the DAK funding has an effect on reducing poverty levels in Indonesia. The results of this study also reinforce previous research conducted by Dewi, et al (2016) which states that DAK has a significant negative relationship to poverty levels through regional spending.

\section{Village Funding Variable (DD) on Poverty Rate}

The results of the Generalized Method of Moment test, the Village Funding variable for the current period $(\mathrm{t})$ obtained a coefficient value of -0.103851 , has a t-statistic of - 4.149993 with a significance of 0.0001 . Significance value less than 0.05 indicates that the current Village Funding ( $\mathrm{t}$ ) has a negative and significant effect on the current Poverty Rate (t), so the third hypothesis is accepted.

The Village Funding that are allocation to the regions through the regency / city Regional Revenue and Expenditure Funding (APBD) are directed to be used to finance governance, development, community development, and community empowerment. The allocation of the Village Funding is one of the commitments of the Authority to develop Indonesia from the periphery by strengthening regions and villages within the framework of the unitary state of the Republic of Indonesia. To improve the quality of the more equitable distribution of Village Funding, in 2018 a reformulation of the Village Funding distribution has been carried out which aims to accelerate poverty alleviation of the village. $\mathrm{AD}$ : $\mathrm{AF}$ ratio changes to $\mathrm{AD}$ : $\mathrm{AF}$ : Affirmation Allocation (AA) with each portion of 77: 20: 3. The existence of Affirmation Allocation (AA) is to take into account the additional allocation to underdeveloped and very villages disadvantaged that have high numbers of poor people. The policy aims to accelerate the reduction of rural poverty.

Apart from the various obstacles encountered in implementing the Village Funding policy, this condition proves that the increase in the Village Funding has an effect on reducing poverty levels in Indonesia. The results of this study also strengthen previous research conducted by Intan and Faisal (2017) which concluded that the Village Funding has a significant influence in reducing poverty levels. 


\section{Variable Poverty Rate of the previous period (t-1) toRate of Poverty The current period (t)}

The results of the Generalized Method of Moment test, Poverty Rate variable of the previous period (t-1) obtained a coefficient value of 0.299148, has a t-statistic of 2.899783 with a significance of 0.0051 . Significance value less than 0.05 indicates that the Poverty Rate of the previous period (t-1) has a positive and significant effect on the Poverty Rate of the current period ( $t$ ), so the fourth hypothesis is accepted.

In this study, it was found that in terms of poverty reduction there were significant inequalities between provinces in Indonesia. Papua Province in the study period had a poverty rate that far exceeded the national average of $28.40 \%$ in 2018 . On the other hand, DKI Jakarta was at $3.55 \%$ below the national average of $9.66 \%$. This shows that the increase in allocations to regions and village funding (TKDD) every year has not been able to reduce poverty evenly.

With the performance of fiscal decentralization policy, this poverty problem can be solved effectively and efficiently. This is caused by the authority's inability to carry out community welfare programs in accordance with national priorities, namely poverty alleviation in Indonesia effectively and efficiently. The authority must be able to optimize in terms of policy formulation, performance, and supervision of the performance of policies to alleviate poverty in Indonesia.

\section{DISCUSSION}

Current allocation funding in the form of General Allocation Funding (DAU) (t) have a positive and significant effect on reducing rural poverty in the current period (t). This phenomenon indicates a linear relationship between the distribution of DAU with the level of poverty. Increasing DAU each year tends to increase poverty in Indonesia. This condition is against the authority's expectation that increasing DAU can reduce poverty, especially in rural areas.

This result is contrary to the expectations of the authority, the possibility of increasing DAU is more used to pay salaries of local authority officials that do not have a direct impact on poverty reduction. Increasing the income of the regional authority apparatus is not followed by an increase in the quality of public services provided to the community. This is supported by the research of Heru Syah P. (2017) who said that the utilization of DAU is not used effectively to reduce poverty, but rather is used more for regional authority expenditure, such as regional apparatus salaries. Increasing the income of the regional authority apparatus is not followed by an increase in the quality of public services provided to the community. This 
phenomenon also makes it possible that the effect of DAU on poverty levels is not immediately felt in the same period. It would be follow up in the next year or the next 2 years.

Allocation funding in the form of the Special Allocation Funding (DAK) of the current period ( $t$ ) has a negative and significant effect on the reduction of rural poverty in the current period $(\mathrm{t})$. Based on the use details, physical and non-physical DAK have more direct impacts on the community compared to DAU, both in the same period and in the previous period. This finding indicates that physical and nonphysical DAK aimed at alleviating poverty, especially in rural areas has been proven. The results of this study also reinforce previous research conducted by Dewi, et al (2016) which states that DAK has a significant negative relationship to poverty levels through regional spending.

Allocation Funding in the form of Village Funding (DD) in the current period (t) has a negative and significant effect on the reduction of rural poverty in the current period (t). The Village Funding that are allocation to the regions through the regency / city Regional Revenue and Expenditure Funding (APBD) are directed to be used to finance authority administration, development performance, community development, and community empowerment. These findings indicate that the increase in the Village Funding in the past 3 years has had a major impact on alleviating rural poverty. The results of development and community empowerment directly affect poverty reduction in rural communities which can aggregately reduce poverty levels in Indonesia. The results of this study also strengthen previous research conducted by Intan and Faisal (2017) which concluded that the Village Funding has a significant influence in reducing poverty levels.

\section{CONCLUSION}

1. Optimizing the income of the local authority apparatus is not followed by an increase in the quality of public services provided to the community. The effect of the General Allocation Funding (DAU) on poverty reduction in Indonesia. The phenomenon found in this study reflects that increasing DAU each year tends to increase poverty in Indonesia. Though, the results are contrary to the expectations of this authority there is a possibility that the increase in DAU is more used to pay salaries of local authority officials who don't have a direct impact on poverty reduction. The findings of this study is to follow up the previous research conducted by Nanga (2006) who found that fiscal allocations in various forms such as tax revenue-sharing, non-tax revenue-sharing, and DAU 
have an impact that tends to exacerbate poverty in Indonesia.

2. Special Allocation Funding (DAK) is aimed to reduce poverty levels in Indonesia. Based on the details of the use of Physical and Non-Physical DAK. It has more direct impact on the community compared to DAU. Next, The provision of public facilities and infrastructure as well as operational support in the administration of public services has a meaningful input in mitigating poverty in Indonesia. Therefore, an increase in the DAK funding has an effect on reducing poverty levels in Indonesia. The results of this study also reinforce previous research conducted by Dewi, et al (2016) which states that DAK has a significant negative relationship to poverty levels through regional spending.

3. The influence of the Village Funding on easing the level of poverty in Indonesia shows that the Village Funding policy is proven that the increase in the Village Funding has an effect on reducing the level of poverty in Indonesia. The results of this study also enrich previous research conducted by Intan and Faisal (2017) which concluded that the Village Funding has a significant influence in reducing poverty levels.

\section{REFERENCES}

Anderson, TW \& Hsiao, C. (1982). Formulation and estimation of dynamic models using panel data. Journal of econometrics, 18(1), 47-82.

Anwar, L. Meilita; Sutomo W. Palar; dan Jacline I. Sumual. (2016). Pengaruh DAU, DAK, PAD Terhadap Pertumbuhan Ekonomi dan Kemiskinan (Kota Manado Tahun 2001 - 2013). Manado: Jurnal Berkala Ilmiah Efisiensi Vol. 16 No. 02.

Arellano, M. \& Bond, S. (1991). Some tests of specification for panel data: Monte Carlo evidence and an application to employment equations. The review of economic studies, 58(2), 277-297.

Arini, S. 2008. Analisis Pengaruh Desentralisasi Fiskal Tingkat Kemiskinan Di Sumatra Barat. Tesis. Fakultas Ekonomi dan Bisnis: Universitas Andalas.

Badan Pusat Statistik Indonesia. (2014). Kajian Indikator Sustainable Development Goals (SDGs). Jakarta: Badan Pusat Statistik.

Baltagi, B. (2008). Econometric analysis of panel data (Vol. 1). Australia: John Wiley \& Sons 
Bappenas. (2011). Analisis Perspektif, Permasalahan dan Dampak Dana Alokasi Khusus (DAK). Jakarta.

Barzelay, Michael. (1991). "Managing Local Development: Lessons from Spain". Policy Sciences. XXIV:3, 271-290.

Bird, RM and Vaillancourt, F. (1998). Fiscal Decentralization in Developing Countries. Cambridge: Cambridge University Press.

Bjornestad, L. (2009). Fiscal Decentralization, Fiscal Incentives, and Pro-Poor Outcomes: Evidence from VietNam. ADB Economics, (168).

Caporale, GM, TH Amor dan C. Rault. (2009). Sources of Real Exchange Rate Volatility and International Financial Integration: A Dynamic GMM Panel Data Approach. Economics and Finance Working Paper Series: 09- 21.

Chambers, Robert. (2007). Participation and Poverty. Society for International Development. Development (2007) 50(2), 20-25. doi: 10.1057/palgrave .development.1100382

De Janvry, Alain and Elisabeth Sadoulet. (2010). Agricultural Growth and Poverty Reduction: Additional Evidence. The World Bank Research Observer 25: 1-20.

Firdaus, M. (2011). Aplikasi Ekonometrika untuk Data Panel dan Time Series. IPB Press: Bogor.

Jolianis. (2016). Analisis Pengaruh PAD, DAU, dan DAK Terhadap Kemiskinan Pada Kabupaten/Kota di Provinsi Sumatera Barat Dengan Pertumbuhan Ekonomi Sebagai Variabel Intervening. Journal of Economic and Economic Education Vol.4 No.2 (192-209).

Kementerian Keuangan Republik Indonesia Direktorat Jenderal Perbendaharaan. (2018). Kajian Fiskal Regional Gabungan 2017: Laporan Khatulistiwa.

Kementerian Keuangan Republik Indonesia Direktorat Jenderal Anggaran. (2014.Postur APBN Indonesia. Jakarta: Direktorat Penyusunan Anggaran.

Kementerian Keuangan RI. (2017). Manfaat Dana Desa dalam Percepatan Pembangunan dan Pengentasan Kemiskinan Desa. Jakarta: Pusat Kebijakan 
APBN Badan Kebijakan Fiskal.

Lalira, Dianti; Amran T. Nakoko; dan Ita Pinkan F. Rorong. (2018). Pengaruh Dana Desa dan Alokasi Dana Desa Terhadap Tingkat Kemiskinan di Kecamatan Gemeh Kabupaten Kepulauan Talaud. Manado: Jurnal Berkala Ilmiah Efisiensi Volume. 18 No. 04.

Litvack, Jennie; J. Ahmad; and RM Bird. 1998. Rethinking Decentralization In Developing Countries. The World Bank Sector Studies Series. The World and Washington DC

Martinez-Vasquez, Jorge and Robert M. McNab. (2001). "Fiscal Decentralization and Economic Growth". International Studies Program Working Paper. Atlanta : Andre Young School of Policy Studies, Georgia State University.

Mulyana, Budi; Subkhan; dan Kuwat Slamet. (2006). Keuangan Daerah: Perspektif Desentralisasi Fiskal dan Pengelolaan APBD di Indonesia. Jakarta: Lembaga Pengkajian Keuangan Publik dan Akuntansi Pemerintah.

Musgrave A. Richard. (1958). The Theory of Public Finance. New York: McGraw-Hill.

Nachrowi D. Nachrowi. (2006). Ekonometrika. untuk Analisis Ekonomi dan Keuangan Cetakan Pertama. Jakarta: Lembaga Penerbit FE UI.

Oates, Wallace E. (2006). On the Theory and Practice of Fiscal Decentralization. IFIR Working Paper No. 2006-05.

Oates, WE (1993). Fiscal decentralization and economic development. National Tax Journal. 46 (3), hal. 237-243

Oates, Wallace E. (1972). Fiscal Federalism. New York: Harcourt Brace Jovanovich.

Paddu, Abdul Hamid. (2010). Pengaruh Desentralisasi Fiskal Terhadap Pertumbuhan Ekonomi dan Ketimpangan Regional di Indonesia. Disertasi: Makassar.

Paulus, Dewi I. Septiyani; Rosalena AM Koleangan; dan Daisy SM Engka. (2016). Analisis Pengaruh PAD, DAU dan DAK terhadap Kemiskinan melalui Belanja Daerah di Kota Bitung. Jurnal Pembangunan dan Keuangan Daerah. 
Putra, Heru S. (2017). The Linkage of Interauthorityal Allocation and Poverty in Indonesia. Jurnal Bina Praja 9 (1):(29-40). Aceh: National Institute of Public Administration.

Rahayu, Sri L. (2014). Dinamika Kemiskinan dan Intervensi Kebijakan Pemerintah. Bandung: Fokusmedia.

Risalam. (2013). Analisis Tingkat Kemiskinan, Ketersediaan Infrastruktur Sekolah, Dan Pertumbuhan Ekonomi Terhadap Kemandirian Fiskal di Kabupaten/Kota Provinsi Jawa Tengah Periode 2007-2011. Economics Development Analysis Journal 2 Halaman 197-208. Semarang: Universitas Negeri Semarang.

Sari, M. Intan dan M Faisal Abdullah. (2017). Analisis Ekonomi Kebijakan Dana Desa Terhadap Kemiskinan Desa Di Kabupaten Tulungagung. Jurnal Ekonomi Pembangunan.

Shah, Anwar, and Zia Qureshi. (1994). Interauthorityal Fiscal Relations in Indonesia. World Bank Discussion Paper 239. Washington, DC

Sidik, M. 2002. Format Hubungan Keuangan Pemerintah Pusat dan Daerah yang Mengacu pada Pencapaian Tujuan Nasional. Direktorat Jenderal Perimbangan Keuangan Pusat dan Daerah. Departemen Keuangan. Jakarta.

Sudewi, A. Ni Nyoman; dan IGAP Wirathi. (2013). Pengaruh Desentralisasi Fiskal dan Pertumbuhan Ekonomi terhadap Kemiskinan di Provinsi Bali. E-Jurnal Ekonomi Pembangunan Universitas Udayana Vol. 2 No. 3 Maret 2013.

Suryawati, Chriswardani. (2005). Memahami Kemiskinan Secara Multidimensional. JMPK Vol. 8 No. 3. September 2005.

Tambunan, Tulus, TH (2011). Perekonomian Indonesia, Kajian Teoritis dan Analisis Empiris. Ghalia Indonesia. Jakarta.

Tiebout, Charles. (1956). A Pure Theory of Local Expenditures. Journal of Political Economy 64(5) 416-424.

Todaro, M., \& Smith, S. (2016). Pembangunan Ekonomi (9 $9^{\text {th }}$ ed.). Jakarta: Erlangga. 
Pemerintah Pusat dan Daerah.

Undang-Undang Nomor 15 Tahun 2017 Tentang Anggaran Pendapatan dan Belanja Nasional (APBN) Tahun 2018.

United Nations, 2015. Transforming our world: the 2030 Agenda for Sustainable Development. A/RES/70/1.

https://sustainabledevelopment.un.org/post2015/transformingourworld, diunduh November 8, 2018.

Verbeek, Marno. (2004). A guide to modern econometrics. 2nd Edition. Chicester : John Wiley \& Sons. Ltd.

Zulyanto, A. (2010). Pengaruh Desentralisasi Fiskal Terhadap Pertumbuhan Ekonomi di Provinsi Bengkulu. Tesis. Program Studi Magister Ilmu Ekonomi dan Studi Pembangunan: Semarang. 